\title{
A STUDY OF 2 TIMOTHY 4:1-8 \\ THE CONTRIBUTION OF EPISTOLARY ANALYSIS AND \\ RHETORICAL CRITICISM ${ }^{1}$
}

Craig A. Smith

The traditional reading of 2 Timothy $4: 1-8$ by scholars, regardless of their view of authorship, has been that Paul is writing his farewell speech or last will and testament to Timothy because his death is imminent. Their reading of 2 Timothy $4: 1-8$ in turn becomes the key text in understanding the situation of the letter. These scholars believe that Paul is passing the baton on to Timothy. Some understand the events and situation recorded to be historical but others suggest they are a creation of the author. The primary aim of this study is to show that 2 Timothy 4:1-8 is not a farewell speech or last will and testament but is a particular literary form and when interpreted as such it leads to a very different understanding of the situation behind the text and the letter. The premise is that if this text is a farewell speech or last will and testament as these scholars suppose, then it must have the same formal features characteristic of these respective types of literature.

Chapter one begins by defining some terms before establishing a method for isolating literary forms. A literary form is a conventional form (i.e. a delimited text with a repeatable identifiable structure not unique to a particular author) which is found embedded within a larger work with its own literary genre. Epistolary Form Criticism, which is an extension of form criticism, is thus 'the examination of the form of letters and of embedded literary forms primarily in terms of structure but also content and function'. It is my view that structure is the primary objective criterion for identifying literary forms, with content and function taking a subordinate role in this process, serving to confirm the results by analysing the structure. Reviewing past form

1 Abstract of a thesis awarded a Ph.D. at the University of Bristol, 2005 supervised by Dr John Nolland and Prof. I. Howard Marshall. 
critics revealed that this is a needed corrective to their emphasis on content and function.

The method for isolating a literary form requires finding written material which has a clear identifiable structure. This pattern must be found repeated elsewhere in contemporary literature. The literary unit must be large enough in size (i.e. not specific words or phrases), preferably a period consisting of large and small unit cola with stereotypical features. Though writers may modify the literary form, the shape of the literary form must not be distorted to the point that it is not recognisable as this type of form. After isolating the literary form the fundamental and optional constituent elements are determined and their respective significance ascertained so that by combining the meaning of the constituent elements the meaning of the whole literary form can be established.

Chapter two is the application of the method created in Chapter 1. It is shown that many Greek and Latin texts inside and outside of the New Testament conform to an identifiable formal pattern; this literary form is called the charge. This form has four necessary elements. The first element is the charge verb which is given in the indicative mood, active voice and first person. The function of charge verb (usually 'I adjure' or 'I order') is to command someone directly and personally who is usually the charger's subordinate or less commonly, his equal. The second element, person charged, is most commonly in the second person ('you') and rarely the third person ('them') and states the one to whom the charge is addressed. The third element, the authority phrase, states the authority by which the charger is giving his command. The effect of the authority phrase is to bring to bear on the chargee an authority recognised to be greater than either party thereby creating a greater urgency and obligation within the chargee to fulfil the content of the charge. This is the key element of the form because it changes a simple command to a solemn charge. The fourth element, content of charge, contains those commands or exhortations required of the chargee. The fifth element (optional), implications of the charge, presents the positive or negative implications of obedience or disobedience to the charge respectively.

The remainder of this chapter is dedicated to comparing the charge form with other similar literary forms (e.g. decrees, edicts, petitions) in order to show its distinct formal structure and function. Interestingly it is shown that the exorcism command (e.g. 'I command you [demon] in 
the name of Jesus Christ "come out of her"'; Acts 16:18) and some of the magic texts used the same structural pattern as the charge and are in fact specific types of the charge form. The charge is used primarily in religious contexts and particularly in the New Testament though the form predates it. New Testament writers have therefore appropriated an existing form and applied it to situations which needed an authoritative command using predominately the name of God or Christ, which for the church was their highest authority and to whom all beings were accountable.

The twofold aim of chapter three is to show that 2 Timothy $4: 1-8$ has the form of a charge and to show it is not, at the same time as being a charge or instead, a farewell speech or last will and testament. Several scholars have labelled material in 2 Timothy as a charge, though on the basis of content and not structural considerations. Applying the method developed in chapter one and the structure ascertained in chapter two shows that 2 Timothy $4: 1-8$ is indeed a charge form, though with two modifications. The structure is:

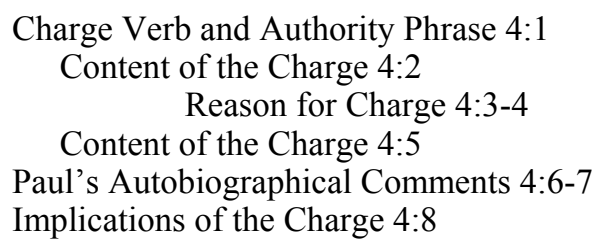

The outline above makes it clear that the shape of the charge is intact though with slight modifications. The gar clause in 4:3-4, Reason for Charge, which is bracketed by the content of charge, thereby creating a small chiasm serves to emphasize why Timothy must obey the charge. In the subsequent gar clause in 4:6-7, Paul's Autobiographical Comments, Paul is presented as the paradigm of one who fulfils the commands in 4:2, 5 and it serves to assure Timothy that he too will receive the crown of righteousness in heaven if he remains faithful to Paul's charge. Therefore 2 Timothy 4:6-7 should not be taken as a causal clause, pointing to the reason why Timothy should obey the commands in $4: 5$ as it is traditionally understood.

Next 2 Timothy 4:1-8 is compared with the form of the farewell speech, testament and Jewish deathbed speeches to show that they are totally dissimilar in terms of structure. Scholars have traditionally understood 4:6-8 to refer to Paul reflecting on his past life and find in these verses clear support for Paul's imminent death and for taking this 
text as a farewell speech or last will and testament. Therefore lexicographical proof is given to show that 4:6-8 refers to Paul reflecting on the trial he has been undergoing. Paul being poured out like a wine drink offering refers not to the pouring out his blood unto death but to his preaching at his trial which, like an Old Testament wine libation, was pleasing to God. He is confident that he has spoken well and that the time of his release from prison is at hand and therefore, by using this statement, he does not refer to his death. The metaphors, running the race and fighting the fight, refer not to his death but more narrowly to his Roman trial which has now finished. Paul believes that he has kept the faith at this most difficult time. Therefore if these statements do not refer to his death, but to his imprisonment and incipient freedom to continue his evangelistic ministry with Mark and Timothy, this is further proof that this text cannot be a last will and testament or farewell speech before his death.

The final chapter seeks to understand the purpose and situation of 2 Timothy 4:1-8 and its contribution to understanding the purpose and situation of 2 Timothy through epistolary and rhetorical analysis. After defending a mixed approach of using epistolary and rhetorical analysis for examining letters, this is then applied to 2 Timothy, in part, to overturn Michael Prior's position. Prior relies heavily on a mirrorreading of the text and concludes that the inclusion of the many imperatives in the letter suggests that Timothy's fidelity as a believer and an evangelist is at stake. This position is rejected for the following one. Paul writes to Timothy in Ephesus where he has met opposition and false teaching. Paul is in prison, having had his first trial where he preached the gospel fully and expects to be released soon. He has a twofold reason for writing 2 Timothy: first, to encourage Timothy to come to Rome as quickly as possible so that they can renew their friendship and prepare to continue their ministry together and second, to assure Timothy that he is persuaded of his sincere faith amidst a difficult situation and to encourage him in his present work and calling. The charge in 2 Timothy 4:1-8 which comes at the end of the body of the letter summarizes the role of a good Christian minister and the general paranetic material of the letter. Paul gives this charge to Timothy because no one is beyond the pale. If Timothy continues to remain faithful in Ephesus and beyond, he will receive a reward. The only baton being passed on is the brief Tychicus will receive when he replaces Timothy (4:12). 